Article

\title{
Emerging and Innovative Techniques for Arsenic Removal Applied to a Small Water Supply System
}

\author{
António A.L.S. Duarte ${ }^{1}{ }^{*}$, Sílvia J.A. Cardoso ${ }^{2}$ and António J. Alçada ${ }^{2}$ \\ 1 Department of Civil Engineering, School of Engineering, University of Minho, Largo do Paço, \\ 4704-553 Braga, Portugal \\ 2 Águas do Zêzere e Côa, SA, Rua Dr. Francisco Pissarra de Matos, 21-r/c, 6300-906 Guarda, \\ Portugal; E-Mails: scardoso@adzc.adp.pt (S.J.A.C.); aalcada@adzc.adp.pt (A.J.A.) \\ * Author to whom correspondence should be addressed; E-Mail: aduarte@ civil.uminho.pt; \\ Tel.: +351-253-604720; Fax: +351-253-604721.
}

Received: 4 November 2009 / Accepted: 7 December 2009 / Published: 11 December 2009

\begin{abstract}
The impact of arsenic on human health has led its drinking water MCL to be drastically reduced from 50 to $10 \mathrm{ppb}$. Consequently, arsenic levels in many water supply sources have become critical. This has resulted in technical and operational impacts on many drinking water treatment plants that have required onerous upgrading to meet the new standard. This becomes a very sensitive issue in the context of water scarcity and climate change, given the expected increasing demand on groundwater sources. This work presents a case study that describes the development of low-cost techniques for efficient arsenic control in drinking water. The results obtained at the Manteigas WTP (Portugal) demonstrate the successful implementation of an effective and flexible process of reactive filtration using iron oxide. At real-scale, very high removal efficiencies of over $95 \%$ were obtained.
\end{abstract}

Keywords: safe drinking water; public health; arsenic removal; emerging techniques; real-scale removal efficiencies; water sources sustainability; Manteigas WTP (Portugal) 


\section{Introduction}

Arsenic in drinking water has been reported as the most widespread geogenic contaminant in water sources worldwide. Groundwater contamination is of global concern and arsenic-associated human health problems have now been recognised in many parts of the world, mainly in developing countries [1]. A wide variety of adverse health effects, including severe skin lesions, cardiovascular and haematological effects, and neurological disturbances effects have been attributed to chronic arsenic exposure, primarily from drinking water [2]. Furthermore, several epidemiological studies have confirmed that chronic arsenic poisoning causes skin and internal cancers [3].

Considering the lethal impact of arsenic on human health, environmental authorities have taken a more stringent attitude towards the presence of arsenic in water. In 1993, the World Health Organization (WHO) had recommended a maximum contaminant level (MCL) of arsenic in drinking water of $10 \mathrm{ppb}$ [4]. The WHO recommendation was adopted by the EU in 2003 (Directive 98/83/EC), thereby revoking the previous $50 \mathrm{ppb}$ limit. The new MCL was later transposed to the Portuguese legislation through Law Decree (DL) no. 236/2001. The drastic reduction of the arsenic MCL from 50 to $10 \mathrm{ppb}$ has led many impoundments, which serve small and medium water supply systems, to become critical for this contaminant. Consequently, drinking water facilities are undergoing several technical and operational changes induced by the non-compliance (though seasonal) of raw water arsenic levels with the new quality standard. These changes concern:

- many Water Treatment Plants (WTP) that require upgrades to address arsenic removal in order to comply with the new lower limit;

- many drinking water supply systems managers that need to build new plants with arsenic removal facilities, since this contaminant has now become a critical parameter.

When arsenic contamination is identified and quantified to be above the MCL, managers are confronted with either finding other water sources or implementing arsenic removal operations. When a safer drinking water source is not available or it becomes too expensive to exploit—one that is both low-arsenic or arsenic-free, and exhibits acceptable microbiological quality-treating raw water for arsenic removal is often the sole viable option to explore. In this case, there is ample justification for the development of innovative removal technologies that are more efficient and economically sustainable for small and medium-sized water supply systems. This issue is very sensible in the context of water scarcity and climate change.

The work presented herein summarises the major processes (conventional and emerging) that can be used for arsenic removal in drinking water treatment, including an analysis of corresponding efficiencies, in order to establish selection criteria of those technologies as a function of the raw water characteristics and/or treatment schemes for existing WTP.

In this context, the authors present a case study describing the rehabilitation of the WTP of Manteigas carried out by the Águas do Zêzere e Côa (AdZC) Company, concerning the development and installation of a suitable arsenic removal facility [5]. Their process decisions and methodological design allowed the managing company to avoid the rash acquisition of an expensive and pre-formatted arsenic removal solution. 


\section{Arsenic Toxicity and Related Health Hazards}

Arsenic naturally occurs in over 200 different mineral forms. Of these, approximately $60 \%$ are arsenates, $20 \%$ sulphides and sulphosalts; while the remaining $20 \%$ include arsenide, arsenite, oxides, silicates and elemental arsenic [6]. Arsenopyrite is produced by hydrothermal activity associated with the intrusion of granitic magma and orogenesis.

Arsenic pollution of natural waters has become an international sanitation problem that currently affects over 40 million people in the World. It was initially reported in Bangladesh and in some countries of Latin America, where groundwater arsenic concentrations surpass $3.4 \mathrm{mg} / \mathrm{L}$ (e.g., in Córdoba, Argentina). In New Zealand, Romania, the Russian Federation, Spain and the USA, arsenic levels between 0.4 and $1.4 \mathrm{mg} / \mathrm{L}$ have been reported for carbonated water springs. In Taiwan, artesian aquifers display concentrations above $1.8 \mathrm{mg} / \mathrm{L}$. In Portugal, water sources that exhibit higher concentrations of arsenic (approximately $800 \mathrm{ppb}$ for groundwater and $60 \mathrm{ppb}$ for surface waters) are generally located in Trás-os-Montes and Alto Douro [7], where the presence of arsenic-rich quartz-sulphur minerals is very common. Minho, Beiras, Ribatejo and Alentejo are additional locations where the legal contaminant concentration $(10 \mathrm{ppb})$ is now exceeded. This has justified the pertinence of epidemiological studies in exposed populations (over many years) to the ingestion of waters containing arsenic concentrations between 10 and $50 \mathrm{ppb}$ (the new and the old legal limit). These studies would allow the evaluation of the real exposure impacts on public health, thereby providing a valuable contribution and support to future and possible proposals for revising and changing the arsenic quality standards for drinking water [8].

Anthropogenic sources of arsenic may result from processing of a variety of ores (e.g., copper, gold, nickel, lead and zinc), from wool and cotton processing, from ingredients of many insecticides and herbicides, from additives to various metal alloys, from mining, from hazardous waste sites, or from the glass and semi-conductor industry. In general, groundwaters exhibit higher concentrations of arsenic species that are more toxic than those found in surface waters. It has been found that when river water - a primary source of drinking water - is polluted by industrial or mining effluents, or by geothermal waste, the arsenic concentration increases [9].

Acute and sub acute poisoning results from ingestion of large quantities of arsenic with lower exposure time, whereas chronic poisoning occurs due to consumption of arsenic contaminated water for a long time period.

Most cases of acute arsenic poisoning occur from accidental ingestion of insecticides or pesticides, being urinary arsenic concentration the best indicator of recent ingestion (1-2 days). The lethal dose of arsenic in acute poisoning ranges from $100 \mathrm{mg}$ to $300 \mathrm{mg}$. Nonspecific gastrointestinal effects such as diarrhoea and cramping, haematological abnormalities including anaemia and leukaemia, peripheral neuropathy (similar to Guillain-Barré syndrome), renal failure, respiratory failure and pulmonary oedema are common features of acute poisoning, which may lead to shock, coma, and even death. Depending on the quantity consumed, death usually occurs within 24 hours to four days [10]. Metabolic changes (such as acidosis, hypoglycaemia and hypocalcaemia) with acute arsenic poisoning are also reported.

Long term arsenic toxicity leads to multisystem disease and the most serious consequence is malignancy. The clinical features of arsenic toxicity vary between individuals, population groups, and 
geographic areas. It is unclear what factors determine the occurrence of a particular clinical manifestation or which body system is targeted. Thus in persons exposed to chronic arsenic poisoning, a wide range of clinical features are common. The onset is insidious with non-specific symptoms of abdominal pain, diarrhoea, and sore throat. The skin is quite sensitive to arsenic and dermatological changes are a common feature related to long term exposure. Skin lesions (hyperkeratosis and dyspigmentation) have been observed even in cases of exposure to levels in the range of 5-10 ppb [1]. Arsenic associated skin cancer, Bowen's disease, is an uncommon manifestation in Asians and may be due to the high skin melanin content and increased exposure to ultraviolet radiation. Arsenic may cause a basal cell carcinoma in a non-melanin pigmented skin. The latent period after exposure may be as long as 60 years. In Latin America, chronic endemic regional hydroarsenism-Hidroarsenicismo Crónico Regional Endémico (HACRE) — manifests itself by the onset of neurological disorders and severe skin lesions (Figure 1).

Figure 1. Skin lesions caused by prolonged ingestion of arsenic.
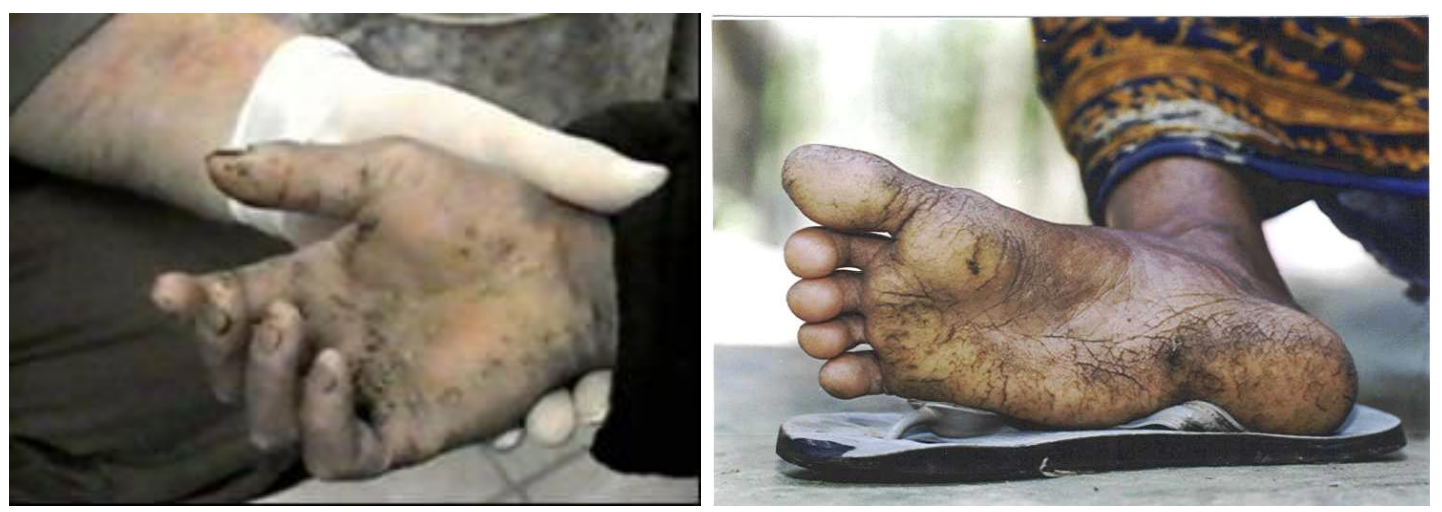

The conclusions of several epidemiological studies confirmed the potentially carcinogenic effect (skin, lung, bladder, kidney, liver, uterus and gallbladder) of a few inorganic species of arsenic when present in high concentrations. This led the WHO to recommend in 1993 a more restrictive guidance value of $10 \mathrm{ppb}$ as the quality standard for drinking water, a value that is five times lower that the previous recommended limit. This drastic reduction in the maximum arsenic limit issued by the WHO has an essentially preventive character, since that parametric value is not yet sufficiently supported by extensive and conclusive epidemiological studies that are urgently warranted. Later on, in 2003, the United States Environmental Protection Agency (USEPA) drafted a proposal issuing final guidelines for cancer risk assessment [11]. The revised document advocates the use of nonlinear relationship between arsenic carcinogenesis and its dose in drinking water.

Since the removal of arsenic from raw water is often the only viable option in order to obtain safe drinking water, it is pertinent to globally intensify applied research efforts. These should address both the quantification of arsenic effects in health (toxicity levels) and the development of innovative technologies for arsenic removal that can be more efficient and sustainable, especially for small water supply systems in rural areas. 


\section{Technologies for Arsenical Removal}

Arsenic removal technologies should meet several basic technical criteria, including robustness, not causing any undue adverse effect on the environment, the ability to provide supply systems with the capacity to produce water in adequate quantity across different seasons and taking into consideration present climate change scenarios, and with the required physical-chemical and microbiological quality.

The presence of high concentrations of arsenic in water sources ought to be analysed in two distinct stages. The first stage consists in verifying the existence of safe alternative sources with very low or null arsenic concentrations that also exhibit adequate physical-chemical and bacteriological quality. In case those exist, the hypothesis of dilution should be pondered by means of conducting an option-specific economic study. When safer, alternative locations are not available or are scarce, thereby preventing the switch of water intakes from arsenic-polluted sources, arsenic removal technologies - conventional and emerging - ought to be used, even if it implies a seasonal operation, e.g., only in periods when the regulation parametric limit is exceeded.

The second stage consists in the definition of the conceptual scheme to adopt for arsenic removal considering the eventual presence of arsenite in the water source. Where the removal is more complex, there are two distinct removal alternatives to consider: carry out a preliminary oxidation step (through conventional or alternative processes) prior to arsenate removal, or use a membrane filtration operation (reverse osmosis or nanofiltration), excluding the arsenite oxidation step [12]. The success of the application of an arsenic removal technique depends on the following factors: parametric value to achieve; raw water arsenic concentration; flow rate to treat; regional lithography; water source and existing treatment scheme [13]. The judicious selection of the most adequate alternatives should be based on a cost-benefit analysis conducted for each one of the possible removal techniques.

To deal efficiently with arsenic removal, regular monitoring is required to identify the factors that control arsenic concentration and arsenic speciation. Such monitoring programmes are not easily established in developing countries and thus, arsenite-oxidizing processes integrated into arsenic removal methods appear as a safety precaution measure in high-risk areas [14].

\subsection{Conventional Technologies}

All of the conventional technologies for arsenic removal rely in a restrict group of basic physical-chemical processes [15]. These include:

- Oxidation/reduction reactions, which reduce or oxidise chemicals, altering their chemical form but not removing arsenic from solution (often used to optimize other processes);

- Precipitation, which causes dissolved arsenic to form a low-solubility solid mineral that can be removed through sedimentation and filtration. When coagulants are added, other dissolved compounds can form solids (known as co-precipitation);

- Adsorption and ion exchange using various solid materials such as iron and aluminium hydroxide flocks, which have a strong affinity for dissolved arsenic. Ion exchange can be considered as a special form of adsorption; 
- Physical exclusion, which uses synthetic membranes that are permeable to certain dissolved compounds but exclude others, and that can act as molecular filters to remove dissolved arsenic along with many other dissolved and particulate compounds.

Coagulation-filtration and softening with lime addition techniques are economical, but display lower efficiencies $(<90 \%)$. Among the most efficient techniques $(>95 \%)$, adsorption using aluminium carbonates stands out as one of the least expensive [16]. Several inorganic-organic hybrid adsorbents bearing thiol groups have been prepared by modifying activated alumina (AA) with mercaptopropyl-functionalized silica under different experimental conditions. Compared with AA, hybrid adsorbents enhance adsorption capacities for arsenite due to the introduction of thiol groups, and still maintain the merit of the AA for arsenate adsorption [17]. However, hybrid adsorbent must be selected by considering not only the adsorption capacity but also the environmental-friendliness and cost-effectiveness of production. Table 1 summarises the removal efficiencies that are normally reported and the main factors responsible for the reduction of those efficiencies.

Table 1. Efficiency of conventional arsenic removal techniques.

\begin{tabular}{|c|c|c|c|c|}
\hline Technology & Chemical reagent & $\begin{array}{l}\text { As (III) } \\
\text { removal } \\
\text { efficiency }(\%)\end{array}$ & $\begin{array}{l}\text { As }(\mathrm{V}) \\
\text { removal } \\
\text { efficiency }(\%)\end{array}$ & Ideal conditions \\
\hline \multirow{2}{*}{$\begin{array}{l}\text { Coagulation-filtration } \\
\text { precipitation } \\
\text { (including lime } \\
\text { softening) }\end{array}$} & Ferric chloride & $<30$ & $90-95$ & $\mathrm{pH} 6-8$ \\
\hline & $\begin{array}{l}\text { Sulphates } \\
\text { (aluminium, copper, } \\
\text { ammonia) }\end{array}$ & $<30$ & $80-90$ & pH 6-6.5 \\
\hline \multirow{2}{*}{ Adsorption } & $\begin{array}{l}\text { Activated carbon or } \\
\text { activated alumina }\end{array}$ & $30-60$ & $>95$ & pH 5.5-6 \\
\hline & $\begin{array}{l}\text { Iron hydroxide } \\
\text { (granular) }\end{array}$ & $30-60$ & $>95$ & $\mathrm{pH}$ near 8 \\
\hline \multirow{2}{*}{ Ion exchange } & \multirow{2}{*}{ Anionic resins } & \multirow{2}{*}{$<30$} & \multirow{2}{*}{$80-95$} & {$\left[\mathrm{SO}_{4}{ }^{2-}\right]<20 \mathrm{mg} / \mathrm{L}$} \\
\hline & & & & {$[\mathrm{SDT}]<500 \mathrm{mg} / \mathrm{L}$} \\
\hline \multirow{2}{*}{$\begin{array}{l}\text { Membrane filtration } \\
\text { (nanofiltration and } \\
\text { reverse osmosis) }\end{array}$} & \multirow{2}{*}{-----} & $60-90$ & $>95$ & \multirow{2}{*}{$\begin{array}{l}\text { Presence of } \\
\text { dissolved } A s\end{array}$} \\
\hline & & $80-95$ & $>95$ & \\
\hline
\end{tabular}

Most of these techniques have been used in arsenic removal at WTPs as adequate solutions for small (500 inhabitants) or large (>1,000,000 inhabitants) water supply systems. However, they show some limitations: addition of chemical products to the water might require complementary treatment; possibility of ion interference (e.g., sulphates) in the removal efficiency; and high installation and operation costs associated with low efficiencies.

Despite its effectiveness, the use of membranes for arsenic removal significantly heightens (approximately 10 times more) the unit costs of the process, often rendering it an unsustainable solution for small water supply systems. 


\subsection{Emerging Physical-Chemical Technologies}

The conventional technologies for arsenic removal referred above are fairly well documented, although some of the systems have only come into prominence in recent decades. Nowadays, extensive research has been conducted towards identifying new technologies for arsenic removal. These focus particularly on low-cost systems that can be applied to small water supply systems, in order to increase efficiency and improve the cost-benefit balance of arsenic removal.

Technology research has also focused on the improvement of existing conventional technologies such as adsorption [18,19], by modifying or using novel adsorbent materials [20,21], or by introducing new chemical oxidation processes. Most of these technologies rely on the oxidation of arsenite followed by filtration through a porous material, where arsenic is removed through adsorption and co-precipitation.

$\mathrm{TiO}_{2}$ immobilization, on a PET surface, combined with co-precipitation of arsenic on iron (III) hydroxides (oxides), could be an efficient way for total inorganic arsenic removal from waters [22,23]. Because of their very strong affinity for arsenic, iron compounds are used by many removal systems. This is also the case for the application implemented and described in the case study presented below.

Recent research work was developed to find a suitable iron (II) to arsenic ratio in water to reduce arsenic to $5 \mathrm{ppb}$ (or lower) through slow sand filtration. It was found that a ratio of 40:1 was necessary to ensure the desired arsenic concentration in the treated effluent [24].

\subsection{Emerging Biological Technologies}

Biological removal processes by indigenous bacteria can play an important role in catalyzing many of the above chemical processes, but relatively little is known about the potential for biological removal of arsenic from water.

Depending on the physical-chemical condition of the environment, some arsenic compounds can be highly soluble, resulting in a high level of bioavailability. Its toxicity and bioavailability depend on its speciation, which in turn, depends on microbial transformations, including reduction, oxidation and methylation. Biological and microbiological methods can represent economically viable as well as environment-harmless alternatives for arsenic removal. Active treatments of arsenic-contaminated waters benefit from the knowledge of arsenic bacterial metabolism. However, many studies were confined to laboratory and need to be tested under real-scale conditions to assess their viability.

The biogeochemical cycle involves several physical-chemical processes (such as oxido-reduction, precipitation/solubilisation, and adsorption/desorption processes) as well as biological mechanisms, especially those involving bacteria, such as As(V) reduction, As(III) oxidation and the various methylation reactions. These reactions protect bacteria from the toxic effects of arsenic (by enhancing the resistance mechanisms), and in the case of some species, contribute to energy metabolism processes [25].

Two major biological mechanisms can describe the reduction of arsenate into arsenite. The first one is related to the detoxification of the cells. Arsenate ions enter the cells via phosphate transporters due to structural homologies with phosphate ions. After reaching the cytoplasm, $\mathrm{As}(\mathrm{V})$ is reduced into As(III) by the enzyme ArsC before being excreted from the cell [26]. The second process, known as 
dissimilatory reduction, has been described in bacteria belonging to various phylogenetic groups including obligate or facultative anaerobic micro-organisms [27]. In this case, bacterial cells gain metabolic energy by "breathing" arsenic (known as respiratory arsenate reductase), since they use $\mathrm{As}(\mathrm{V})$ as an electron acceptor [28]. These two systems play a non-negligible role in the solubilisation of arsenic leading to major contaminations of aquatic environments.

A wide range of bacteria isolated from various contaminated environments were described for their ability to synthesize arsenite and thus to oxidize As(III) enzymatically. They include heterotrophic bacteria as well as chemoautotrophic bacteria in which As(III) serve as an electron donor reducing oxygen or nitrate. In this latter case, the energy produced is used to fix $\mathrm{CO}_{2}$, which provide bacteria with the carbon required for growth. In populations where both heterotrophic and chemoautotrophic bacteria are present, heterotrophic As(III)-oxidizing bacteria can develop using organic substances synthesized by chemoautotrophic bacteria [29]. The biological oxidation of As(III) to As(V) by iron and manganese oxidizing bacteria has been reported and it was also confirmed that trivalent arsenic can be efficiently treated without any additional use of chemicals in this bioprocess [30]. The bioconversion of arsenite can also be accomplished via methylation or oxidation-reduction of the arsenic species found in the water. Their bioconversion efficiency can be increased by genetic modification of the intervening microorganisms [31].

The study of microbial biofilms metal dynamics in acid rock drainage provided evidence of the stable accumulation of metals in these bioreactors, in which secrete polymers are able to immobilize metal compounds by passive sequestration processes, avoiding its use to develop bioremediation methods. In the presence of arsenic, bacteria such as $H$. arsenicoxydans produce large amounts of exopolymers that can be used to detoxify natural waters contaminated with arsenic [32].

Arsenic mobility in aquifers is determined by complex interactions of hydrology, water chemistry, and biological processes. Anaerobic microorganisms play an important role in the release of arsenic in iron-rich aquifers, where arsenic is typically sequestered by iron minerals. Since As(V) reduction is chemically slow, accelerated reduction in natural systems is often achieved biologically [33]. The observed transient release is especially relevant to dynamic (flowing) systems, where release of As(III) has been observed in the presence of bacterial iron and arsenic reduction [34]. Bacterial sulphate reduction is recognised as a mechanism for sequestering metals in contaminated environments, primarily through precipitation of metal sulphides. The sulphide produced by bacteria can reduce $\mathrm{As}(\mathrm{V})$ and precipitate As(III) in sulphide phases [35].

New developments in the biotechnological field have focused on phyto-remediation and biofiltration processes [36,37] that have revealed to be efficient and environmentally sustainable. In phyto-remediation, plant and fungal biomass is used as a renewable adsorbing material in a process that is similar to chemical compound removal. The adsorbing capacity of this biomass is superior to that of activated carbon and of some synthetic resins used in water treatment.

A few of the most promising emerging technologies use UV radiation, solar radiation and/or biological processes (bacterial or plant action) for arsenite removal. For example, the conversion of arsenite surpasses $95 \%$ when UV or solar radiation is used in the presence of iron or sulphites [38].

Table 2 presents a comparative synthesis of the main emerging techniques for arsenic removal in water treatment (adapted from [12]). 
Table 2. Comparison of the main emerging techniques for arsenic removal.

\begin{tabular}{|c|c|c|c|c|}
\hline Oxidation process & Parameters & $\begin{array}{c}\text { Removal } \\
\text { efficiency } \\
(\%)\end{array}$ & Advantages & Disadvantages \\
\hline $\begin{array}{l}\text { UV Ray and sun } \\
\text { light in presence of } \\
\text { iron }\end{array}$ & $\begin{array}{l}\mathrm{As}_{0}=10 \mathrm{mg} / \mathrm{L} \\
\mathrm{pH}=1.5-3 \\
\mathrm{Fe}_{0}=180 \mathrm{mg} / \mathrm{L} \\
\mathrm{Fe}(\mathrm{II}) / \mathrm{As}(\mathrm{III})=24\end{array}$ & $>96$ & No use of chemicals & $\mathrm{pH}$ is lower \\
\hline $\begin{array}{l}\text { UV Ray in presence } \\
\text { of sulphite }\end{array}$ & $\begin{array}{l}\mathrm{As}_{0}=0.47 \mathrm{mg} / \mathrm{L} \\
\mathrm{pH}=9 \\
\text { air bubble supplied }\end{array}$ & $>96$ & $\begin{array}{l}\text { Effluent amenable to all } \\
\text { techniques for } \mathrm{As}(\mathrm{V}) \\
\text { removal }\end{array}$ & $\begin{array}{l}\text { Sulphite content } \\
\text { influences the } \\
\text { efficiency }\end{array}$ \\
\hline $\begin{array}{l}\text { Iron-oxidizing } \\
\text { bacteria in presence } \\
\text { of } \mathrm{Fe} \text { and } \mathrm{Mn}\end{array}$ & $\begin{array}{l}\mathrm{As}_{0}=35.60 \mathrm{ppb} \\
\mathrm{pH}=7.2 \\
\mathrm{Fe}_{0}=2.8 \mathrm{mg} / \mathrm{L} \\
\mathrm{Mn}_{0}=0.6 \mathrm{mg} / \mathrm{L}\end{array}$ & $>80$ & $\begin{array}{l}\text { No use of chemical; } \\
\text { cheaper and eco-friendly; } \\
\text { indigenous microbes }\end{array}$ & Not well established \\
\hline $\begin{array}{l}\text { Sulphate-reducing } \\
\text { bacteria }\end{array}$ & $\begin{array}{l}\mathrm{As}_{0}=10 \mathrm{mg} / \mathrm{L} \\
\mathrm{pH}=4.5-7 \\
\mathrm{Fe}_{0}=20 \mathrm{mg} / \mathrm{L}\end{array}$ & $>78$ & $\begin{array}{l}\text { No use of chemical; } \\
\text { cheaper and eco-friendly; } \\
\text { indigenous microbes }\end{array}$ & Not well established \\
\hline
\end{tabular}

\subsection{Alternative Technologies}

Some alternative safe water options applied in West Bengal and Bangladesh include clay filters, deep tube wells, dug wells, surface and rainwater harvesting and solar distillation. Solar distillation techniques use the sun's energy to evaporate water, which is then re-condensed. This process of evaporation and re-condensation separates all chemicals, including arsenic, from the water [16].

The SORAS (Solar Oxidation and Removal of Arsenic) process has been used in the rural Andes regions in Latin America. It is based on the adsorption of $\mathrm{As}(\mathrm{V})$ onto iron oxides and hydroxides using UV radiation [33-35] and the addition of citrate as a catalyst for the formation of oxidising radicals that allow the conversion of arsenite to arsenate (Figure 2).

Figure 2. Arsenic removal using the SORAS process.
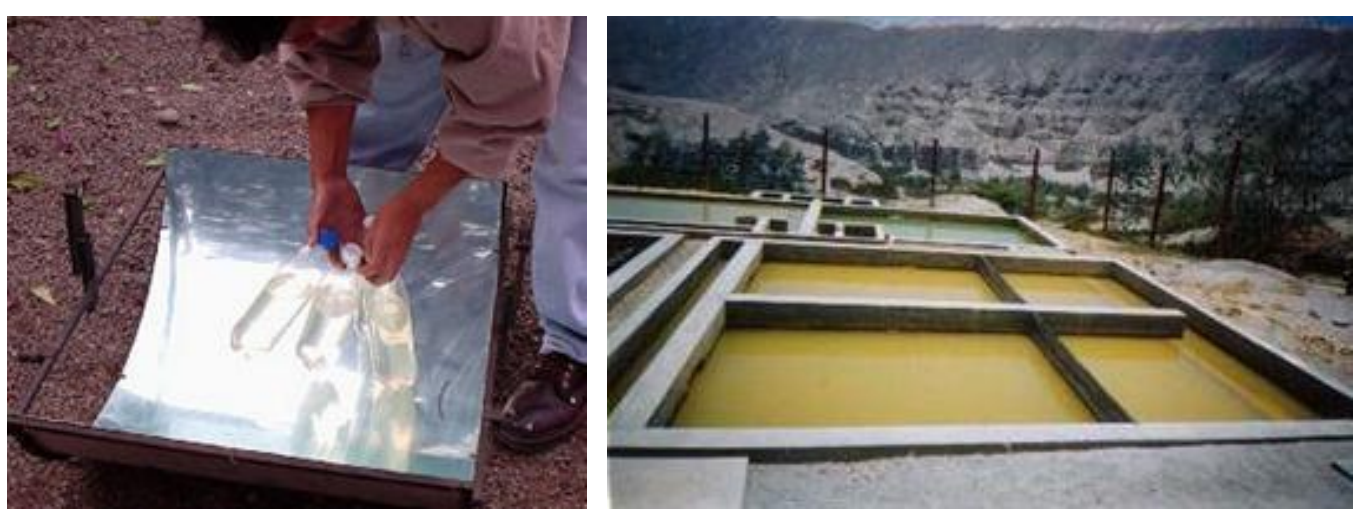

In this context, the combination of solar oxidation with one of the conventional adsorption processes might be a pertinent development towards yet another promissory alternative to arsenic 
removal. The goal would be to optimise the SORAS process by incorporating complementary conventional techniques, thereby increasing its reliability [12]. To that effect, it was proposed that a UV radiation measurement cell be programmed so that the water to treat is automatically re-routed to a chemical oxidation process, whenever the available UV radiation is less than that required for arsenite oxidation. This alternative technology appears as particularly suitable for small and medium-size water supply systems. By integrating a solar radiation (renewable energy source) oxidation technology with conventional reactive filtration or adsorption processes, it is also aiming for the reduction of arsenic removal costs.

\section{Case Study: Rehabilitation of the WTP of Manteigas}

\subsection{Problem and Scope Definition}

The municipality of Manteigas is served by the public water supply to the Manteigas sub-system, whose intake is located in springs from the Portuguese Estrela Mountain massif (Figure 3). The hydrogeological environment features mineralisation outcroppings that are rich in arsenopyrite generally associated to phyllite, meta-greywacke and quartzite. Consequently, raw water from the Paulo Luís Martins spring-the main source supplying the 2002-rehabilitated WTP of Manteigas - shows an annual average arsenic concentration of $12 \mathrm{ppb}$, a value that is slightly above the legal limit of $10 \mathrm{ppb}$.

Figure 3. Manteigas water supply sub-system and the location of its WTP.

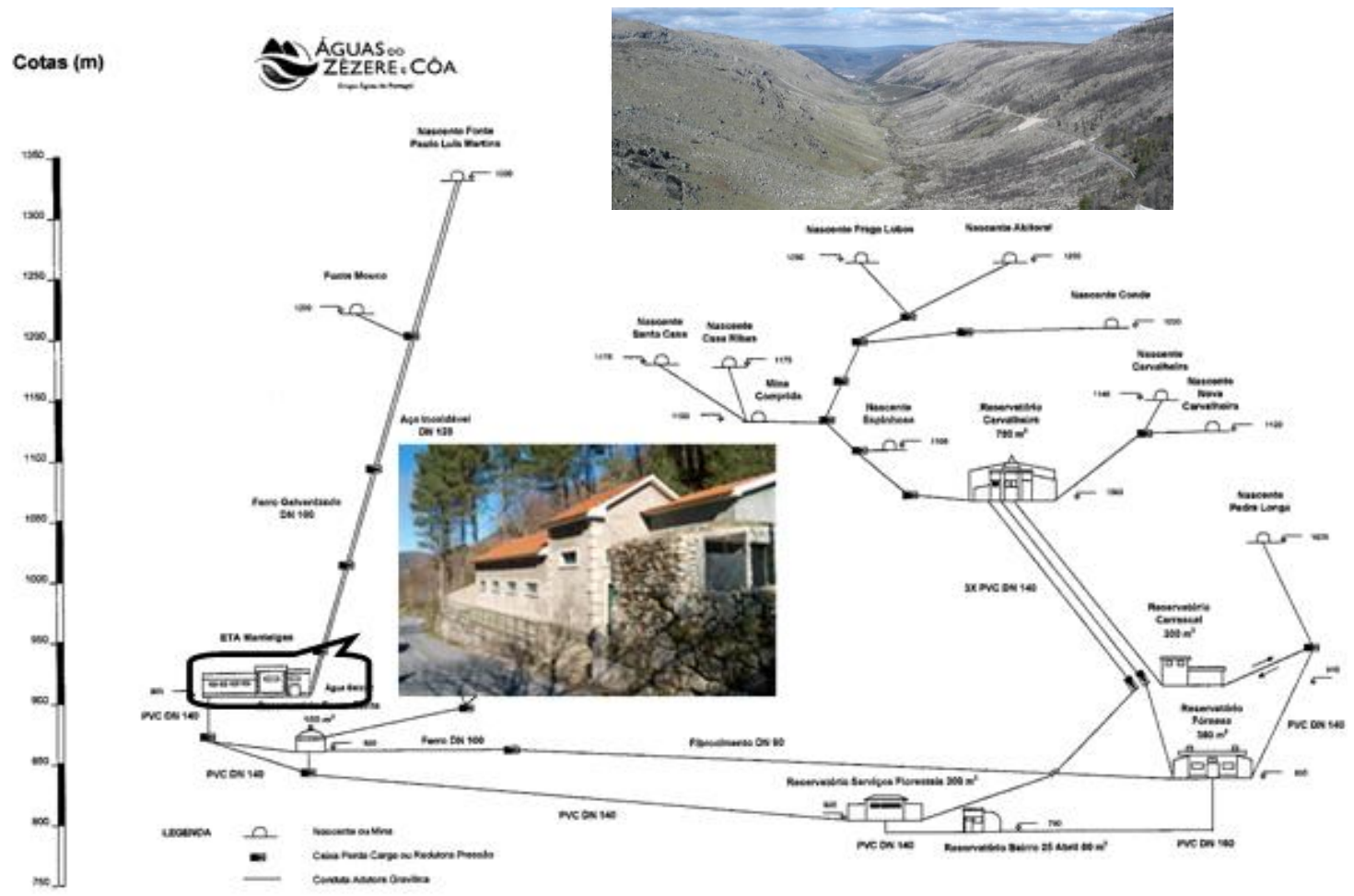

The AdZC Company has been conducting analytical monitoring of the influent raw water at the WTP since 2002. Their monitoring reports confirm the expected seasonal variation of arsenic 
concentrations between 9 and 18 ppb. Lower values are observed during dry seasons and higher values correspond to periods of greater precipitation [5].

At the time of the WTP rehabilitation, it was not possible to implement a sustainable solution for addressing the non-compliance issue, since the options available were not able of adjusting to the limitations and specificity of the small water supply system, including the need to remove very small quantities of arsenic. Limited space availability and the sub-system's small service size - approximately 3,000 inhabitants - compromised the viability and the economic sustainability of accommodating a more complex solution for arsenic removal.

Aside from equipment cost, the WTP would require expansion onto adjacent land, which would imply additional expropriation costs. Such an investment would compromise the balance of the existing economic model, leading to an increase in tariffs that would eventually become unfeasible.

\subsection{Methodology and Laboratorial-Scale Results}

The AdZC Company promoted internal research work aiming to develop an effective arsenic removal process that would suit the characteristics and size of the sub-system. The methodology included two distinct phases. Phase 1 consisted of laboratory-scale experimental trials that were carried-out in order to evaluate the removal efficiencies of pre-selected conventional techniques. Results from these trials allowed the later testing - phase 2-of the most efficient alternatives at full-scale, taking into account the real hydraulic conditions at the WTP.

The pre-selected techniques were based on a scheme consisting of oxidation using chlorine dioxide followed by coagulation with aluminium sulphate and sand filtration. The results of the first set of experimental trials (Figure 4) produced removal efficiencies above 37\% for raw water exhibiting an initial concentration of $10 \mathrm{ppb}$. These removal efficiencies were independent of the coagulant dosage in the experiments.

Figure 4. Laboratory experimental trials for the selection of the most effective and viable methods.
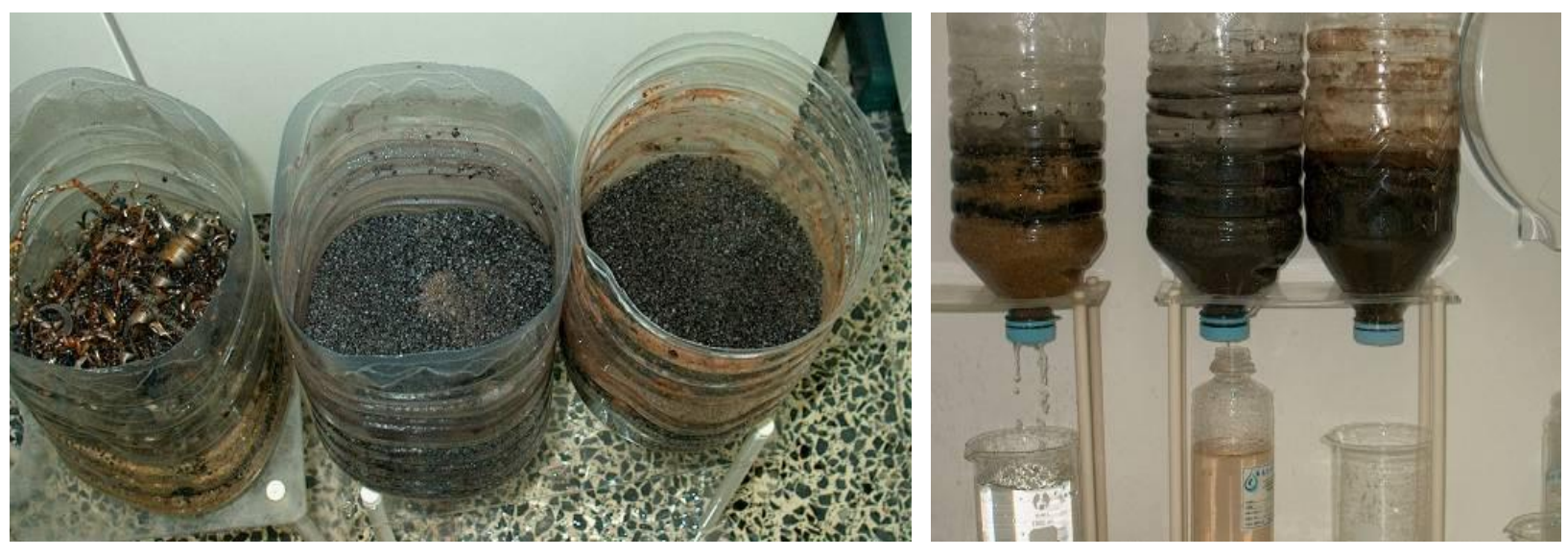

A second set of laboratory trials was conducted using a raw water sample with an initial concentration of $18 \mathrm{ppb}$. Removal efficiencies between 77 and $88 \%$ were attained through a 
combination of "oxidation + filtration" or "oxidation + coagulation + filtration" processes. Table 3 summarises the six different laboratorial procedures and the obtained results.

Table 3. Results of the second stage of laboratory trials for arsenic removal.

\begin{tabular}{clc}
\hline Sampling & \multicolumn{1}{c}{ Process description } & \multicolumn{1}{c}{ Arsenic (ppb) } \\
\hline Raw water & \multicolumn{1}{c}{\begin{tabular}{c}
\multicolumn{1}{c}{ Oxidation with sodium hypochlorite $(0.33 \mathrm{mg} / \mathrm{L})$} \\
Sand filtration
\end{tabular}} & 2 \\
\hline 2 & $\begin{array}{l}\text { Oxidation with sodium hypochlorite }(0.33 \mathrm{mg} / \mathrm{L}) \\
\text { Coagulation with aluminium salt }(10 \mathrm{ppm}) \\
\text { Sand filtration }\end{array}$ & 4 \\
\hline 3 & $\begin{array}{l}\text { Oxidation with sodium hypochlorite }(0.33 \mathrm{mg} / \mathrm{L}) \\
\text { Coagulation with aluminium salt }(20 \mathrm{ppm}) \\
\text { Sand filtration }\end{array}$ & 2 \\
\hline 4 & $\begin{array}{l}\text { Oxidation with chlorine dioxide }(0.38 \mathrm{mg} / \mathrm{L}) \\
\text { Sand filtration }\end{array}$ & 3 \\
\hline 5 & $\begin{array}{l}\text { Oxidation with chlorine dioxide }(0.38 \mathrm{mg} / \mathrm{L}) \\
\text { Coagulation with aluminium salt }(10 \mathrm{ppm}) \\
\text { Sand filtration }\end{array}$ & 3 \\
\hline & $\begin{array}{l}\text { Oxidation with chlorine dioxide }(0.38 \mathrm{mg} / \mathrm{L}) \\
\text { Coagulation with aluminium salt }(20 \mathrm{ppm}) \\
\text { Sand filtration }\end{array}$ & 2 \\
\hline
\end{tabular}

Note that at this scale the hydraulic conditions tested did not match the full-scale conditions observed at the WTP. Based on the laboratorial results, a pilot-installation was tested at the WTP. It consisted of a double-media pressure filter $(0.20 \mathrm{~m}$ sand and $0.05 \mathrm{~m}$ granulated coal $)$ preceded by pre-oxidation with sodium hypochlorite. The first set of results was not satisfactory because the concentration of arsenic in the filter effluent was a non-compliant, albeit slightly, $11 \mathrm{ppb}$ (39\% removal).

In order for such a treatment scheme to work, the WTP would have to be fitted with a pre-oxidation process followed by coagulation and filtration steps, which would result in a heavy and costly construction intervention. The results obtained did not support this option and thus, it became necessary to ponder other treatment alternatives, particularly those of easier implementation.

\subsection{Real-Scale Implementation and Results}

An emerging arsenic removal technology-reactive filtration process based on arsenic adsorption onto iron oxide - was selected for testing. A series of laboratory trials was conducted to simulate the operation of a sand and iron oxide filter, using raw water presenting an arsenic concentration of $12 \mathrm{ppb}$. The final results showed arsenic levels in the filtered water to be below $1 \mathrm{ppb}$, achieving very high removal efficiency (near 95\%). These quite satisfactory results demonstrated that the problem could be solved through a viable, effective, simple, economical and rather simple system. 
Given the high removal efficiency obtained during the experimental trials, a filter was installed at the WTP using iron oxide adsorbent material designed to treat only a fraction $\left(10 \mathrm{~m}^{3} \times \mathrm{h}^{-1}\right)$ of the maximum flow rate $\left(35 \mathrm{~m}^{3} \times \mathrm{h}^{-1}\right)$ required by this water supply network. This ensured the advantageous possibility of retrofitting onto existing tanks with no need for additional space occupation (Figure 5).

Figure 5. Installation of the reactive filter using iron oxide adsorbent medium.
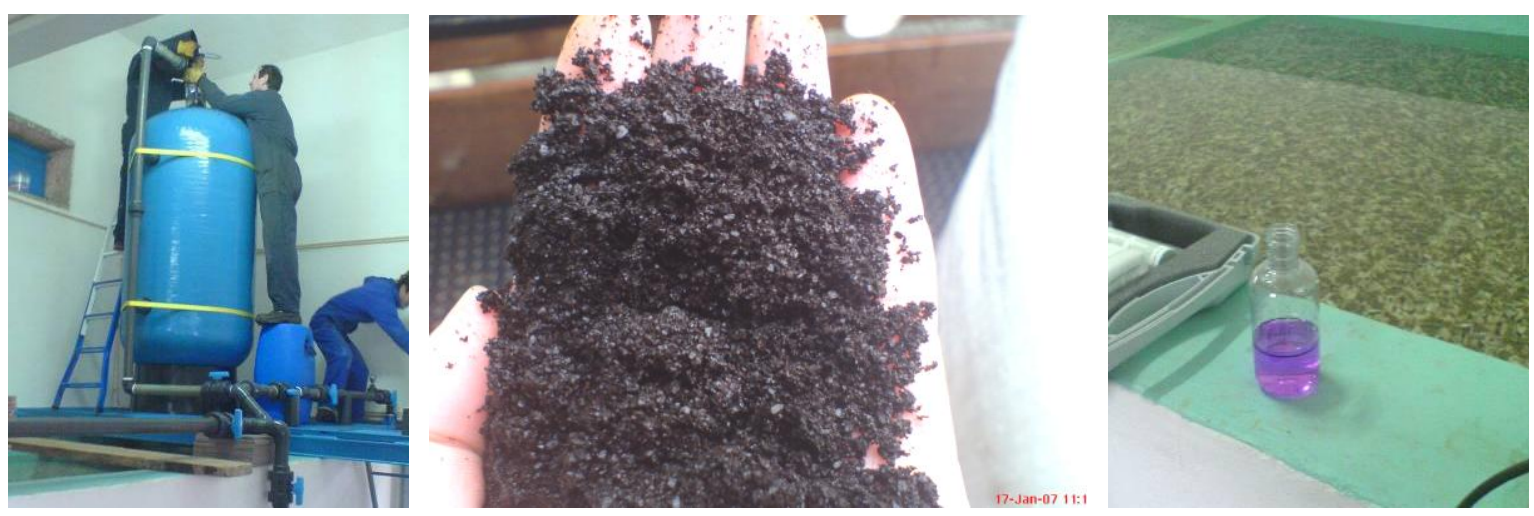

The combination of filtered and unfiltered flows $\left(25 \mathrm{~m}^{3} \times \mathrm{h}^{-1}\right)$ allowed for a final water arsenic concentration below 8 ppb, as depicted in Figure 6.

Figure 6. Arsenic concentration in the treated water of the Manteigas WTP.

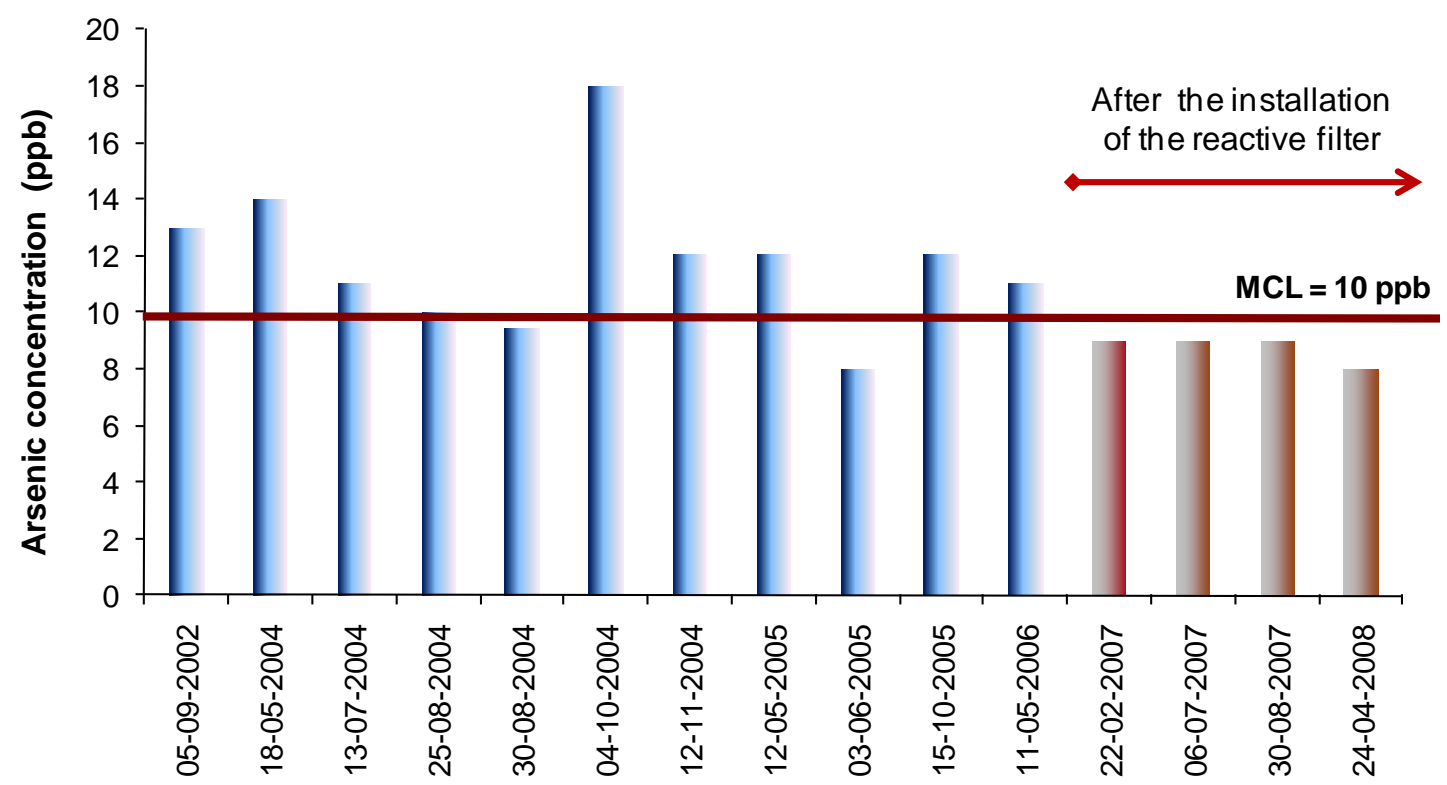

The adequacy of this solution lies also in its adaptability to future legal requirements. It is conceivable that the flexibility of operation could be easily adapted to comply with lower arsenic levels, should they be imposed in the future. As designed, a simple adjustment to the filtered/unfiltered water ratio could mean continuing compliance with future more restrictive drinking water quality standards. 


\section{Conclusions}

The presence and levels of arsenic in natural water sources must be periodically controlled, since the mechanisms that foster the prevalence of high concentrations are many and difficult to identify. However, by identifying risk areas, that is, regions where natural waters normally present high arsenic concentrations, it is possible to promote the establishment of arsenic hazardous criteria to feed Water Safety Plan risk analysis and risk management approaches.

Treating arsenic-polluted dinking water is vital as an instrument of public health prevention policies, since acute and chronic exposure to arsenic can cause a variety of diseases, including fatal cancers. Unfortunately, the full extent of arsenic-related health problems has not yet been fully identified and quantified.

Available arsenic removal technologies are generally complex, expensive and often inadequate for As(III). Therefore, it is of paramount importance that adequate and sustainable treatment options are selected in order to comply with increasingly more stringent quality standards. Ideally, these should be supported by systematic epidemiological studies that are all encompassing and conclusive.

The progressive reduction in the number of water sources suitable for public supply, the increasingly restrictive nature of quality standards for drinking water, and the potential impacts of climate change in the quantities of potable water available, make the need for alternative, sustainable and low-cost arsenic removal technologies all the more pertinent. In this context, the utilisation of new adsorbing materials and bio-oxidation techniques take on particular relevance.

The solution for the financial and operational constraints usually endured by managing entities of small and medium-size public water supply systems must include the adoption of arsenic removal methodologies based on a combination of conventional, alternative and emerging processes. Not only should these aim for significant reductions of operation costs, they should also help prevent the rash acquisition of expensive and pre-formatted solutions that may not always allow the control and deep knowledge of removal mechanisms.

The results obtained demonstrate the successful implementation of an effective and economically sustainable solution for correcting arsenic levels in raw water with excellent microbiological quality. The treatment option selected used technology based on a reactive filtration process that uses iron oxide as an adsorbent and that allowed for very high removal efficiencies (over 95\%).

The case described in this research work constitutes a good example of the research effort initiated and developed by a water supplier that, using the available in-house human resources and expertise, was able to implement a rather effective and low-cost solution at the WTP of Manteigas.

\section{References}

1. Nordstrom, D.K. Worldwide occurrences of arsenic in groundwater. Science 2002, 296, 2143-2145.

2. Yoshida, T.; Yamanchi, H.; Jun, G.F. Chronic health effect in people exposed to arsenic via the drinking water: dose-response relationship in review. Toxicol. Appl. Pharmacol. 2004, 198, 243-252. 
3. Lamm, S.H.; Engel, A.; Kruse, M.B.; Feinleib, M.; Byrd, D.M.; Lai, S.; Wilson, R. Arsenic in drinking water and bladder cancer mortality in the US: an analysis based on 133 US countries and thirty years of observation. J. Occup. Environ. Med. 2004, 46, 298-306.

4. Guidelines for Drinking Water Quality; World Health Organisation: Geneva, Switzerland, 1993; p. 41.

5. Cardoso, S.J.A.; Alçada, A.J. Correcção dos níveis de arsénio na ETA de Manteigas. In Proceedings of 13th ENaSB-Conference on Sanitary and Environmental Engineering, Lisbon, Portugal, October 14-17, 2008.

6. Ávila, P.; Pereira, M.R.; Novais, H.; Ferreira, A. Arsénio nos solos, sedimentos e águas na envolvente da mina do Tuela (Vinhais, NE Portugal). In Proceedings of VII National Congress of Geology, Lisbon, Portugal, June 29-July 13, 2006.

7. Oremland, S.; Stolz, J.F. Ecology of arsenic. Science 2003, 300, 939-944.

8. Smedley, P.L.; Kinniburgh, D.G. A review of the source, behaviour and distribution of arsenic in natural waters. Appl. Geochem. 2002, 17, 517-568.

9. Duarte, A.A.L.S.; Cardoso, S.J.A.; Alçada, A.J. Remoção de arsénio em sistemas de abastecimento de água. Um caso de estudo. Águas Resíduos 2009, 9, 28-37.

10. Ratnaike, R.N. Acute and chronic arsenic toxicity. Postgrad. Med. J. 2003, 79, 391-396.

11. Draft Final Guidance for Carcinogen Risk Assessment Forum; US Environmental Protection Agency (USEPA): Washington, DC, USA, 2003.

12. Cunha, P.D.R; Duarte, A.A.L.S. Remoção de arsénio em águas para consumo humano. In Proceedings of 13th ENaSB-Conference on Sanitary and Environmental Engineering, Lisbon, Portugal, October 14-17, 2008.

13. Mondal, P.; Majumder, C.B.; Mohantya, B. Laboratory based approaches for arsenic remediation from contaminated water: recent developments. J. Hazar. Mater. 2006, 137, 464-479.

14. Katsoyiannis, I.A.; Hugh, S.J.; Ammann, A.; Zikoudi, A.; Hatziliontos, C. Arsenic speciation and uranium concentrations in drinking water supply wells in Northern Greece: correlations with redox indicative parameters and implications for groundwater treatment. Sci. Total Environ. 2007, 383, 128-140.

15. Johnston, R.; Heijnen, H. Safe water technology for arsenic removal. In Technologies for Arsenic Removal from Drinking Water; Ahmed, M.F., Ali, M.A., Adeel, Z., Eds.; Bangladesh University of Engineering and Technology: Dhaka, Bangladesh, 2001.

16. National Drinking Water Advisory Council (NDWAC). Final Report of the Arsenic Cost Working Group to the National Drinking Water Advisory Council; USEPA: Washington, DC, USA, 2001.

17. Hao, J.M.; Han, M.J; Meng, X.G. Preparation and evaluation of thiol-functionalized activated alumina for arsenite removal from water. J. Hazar. Mater. 2009, 167, 1215-1221.

18. Siegel, M.; McConnell, P.; Ilges, A.; Chen, H.-W.; Ghassemi, A.; Thompson, R. Development and evaluation of innovative arsenic adsorption technologies for drinking water by the arsenic water technology partnership. In Proceedings of the National Groundwater Association Meeting on Naturally Occurring Contaminants Conference, Albuquerque, NM, USA, February 6-7, 2006.

19. Mohan, D.; Pittman, C.U., Jr. Arsenic removal from water/wastewater using adsorbents-a critical review. J. Hazard. Mater. 2007, 142, 1-53. 
20. Pena, M.E.; Korfiatis, G.P.; Patel, M.; Lippincott, L.; Meng, X.G. Adsorption of As(V) and As(III) by nanocrystalline titanium dioxide. Water Res. 2005, 39, 2327-2337.

21. Boddu, V.M.; Abburi, K.; Talbott, J.L.; Smith E.D.; Haasch, R. Removal of As(III) and As(V) from aqueous medium using chitosan-coated biosorbent. Water Res. 2008, 42, 633-642.

22. Fostier, A.H.; Pereira, M.D.S.S.; Rath S.; Guimarães, J.R. Arsenic removal from water employing heterogeneous photocatalysis with $\mathrm{TiO}_{2}$ immobilized in PET bottles. Chemosphere 2008, 72, 319-324.

23. Mendes, G.; Bellato, C.R.; Marques, J.D. Heterogeneous photocatalysis with $\mathrm{TiO}_{2}$ for the oxidation of arsenic and its removal from water by co-precipitation with ferric sulphate. Quim. Nova 2009, 32, 1471-1476.

24. Pokhrela, D.; Viraraghavan, T. Biological filtration for removal of arsenic from drinking water. $J$. Environ. Manage. 2009, 90, 1956-1961.

25. Lièvremont, D.; Bertin, P.N.; Lett, M.C. Arsenic in contaminated waters: biogeochemical cycle, microbial metabolism and biotreatment processes. Biochimie 2009, 91, 1229-1237.

26. Mukhopadhyay, R.; Rosen, B.P. Arsenate reductases in prokaryotes and eukaryotes. Environ. Health Perspect. 2002, 110, 745-748.

27. Paez-Espino, D.; Tamames, J.; de Lorenzo, V.; Canovas, D. Microbial responses to environmental arsenic. BioMetals 2009, 22, 117-130.

28. Macy, J.M.; Santini, J.M.; B.V.; Pauling, B.V.; O’Neill, A.H.; Sly, L.I. Two new arsenate/sulphate-reducing bacteria: mechanisms of arsenate reduction. Arch. Microbiol. 2000, 173, 49-57.

29. Battaglia-Brunet, F.; Dictor, M.C.; Garrido, F. An arsenic(III)-oxidizing bacterial population: selection, characterization, and performance in reactors. J. Appl. Microbiol. 2002, 93, 656-667.

30. Casiot, C.; Morin, G.; Jullot, F.; Burneel, O.; Personne, J.C.; Leblanc, M.; Duquesne, K.; Bonnefoy, V.; Poulichet, F.E. Bacterial immobilization and oxidation of arsenic in acid mine drainage (Carnoules Creek, France). Water Res. 2003, 37, 2929-2936.

31. Kostal, J.; Yang, R.; Nu, C.H.; Mulchandani, A.; Chen, W. Enhanced arsenic accumulation in engineered bacterial cells expressing ArsR. Appl. Environ. Microbiol. 2004, 70, 4582-4587.

32. Muller, D.; Médigue, C.; Koechler, S.; Barbe, V.; Barakat, M.; Talla, E.; Bonnefoy, V.; Krin, E.; Arsène-Ploetze, F.; Carapito, C.; Chandler, M.; Cournoyer, B.; Cruveiller, S.; Dossat, C.; Duval, S.; Heymann, M.; Leize, E.; Lieutaud, A.; Lièvremont, D.; Makita, Y.; Mangenot, S.; Nitschke, W.; Ortet, P.; Perdrial, N.; Schoepp, B.; Siguier, P.; Simeonova1, D.D.; Rouy, Z.; Segurens, B.; Turlin, E.; Vallenet, D.; van Dorsselaer, A.; Weiss, S.; Weissenbach, J.; Lett, M.C.; Danchin, A.; Bertin, P.N. A tale of two oxidation states: bacterial colonization of arsenic-rich environments. PLoS Genet. 2007, 3, 518-530.

33. Saalfield, S.L; Bostick, B.C. Changes in iron, sulfur, and arsenic speciation associated with bacterial sulfate reduction in ferrihydrite-rich systems. Environ. Sci. Technol. 2009, 43, 8787-8793.

34. Herbel, M.; Fendorf, S. Transformation and transport of arsenic within ferric hydroxide coated sands upon dissimilatory reducing bacterial activity. ACS Symp. Ser. 2005, 915, 77-90.

35 Kaksonen, A.H.; Puhakka, J.A. Sulfate reduction based bioprocesses for the treatment of acid mine drainage and the recovery of metals. Eng. Life Sci. 2007, 7, 541-564. 
36. Katsoyiannis, I.A.; Zouboulis, A.I. Application of biological processes for the removal of arsenic from groundwater. Water Res. 2004, 38, 17-26.

38. Murugesan, G.S.; Sathishkumar, M.; Swaminathan, K. Arsenic removal from groundwater by pre-treated waste tea fungal biomass. Bioresource Technol. 2006, 97, 483-487.

39. Zaw, M.; Emett, M.T. Arsenic removal from water using advanced oxidation processes. Toxicol. Letter 2002, 133, 113-118.

40. Wegelin, M.; Getcher, D.; Hug, S.; Mahmud, A. SORAS - a simple arsenic removal process. In Proceedings of 26th WEDC Conference-Water, Sanitation and Hygiene: Challenges of the Millennium, Dhaka, Bangladesh, November 5-9, 2000.

41. Meichtry, J.M.; Lin, H.J.; Fuente, L.; Levy, I.K.; Gautier, E.A.; Blesa M.A.; Litter M. Low-cost $\mathrm{TiO}_{2}$ photocatalytic technology for water potabilization in plastic bottles for isolated regions. $J$. Sol. Energ-T ASME 2007, 129, 119-126.

42. Zhang, F.S.; Itoh, H. Photocatalytic oxidation and removal of arsenite from water using slag-iron oxide- $\mathrm{TiO}_{2}$ adsorbent. Chemosphere 2006, 65, 125-131.

(C) 2009 by the authors; licensee Molecular Diversity Preservation International, Basel, Switzerland. This article is an open-access article distributed under the terms and conditions of the Creative Commons Attribution license (http://creativecommons.org/licenses/by/3.0/). 